\title{
Arab Women in Science, Technology, Engineering and Mathematics Fields: The Way Forward
}

\author{
Samira I. Islam ${ }^{1, *}$ \\ ${ }^{1}$ Head of Drug Monitoring Unit, King Fahd Medical Research Center, Jeddah 21411, K.S.A. \\ *Correspondence: Head of Drug Monitoring Unit, King Fahd Medical Research Center, P.O. Box 488, Jeddah 21411, \\ K.S.A. Tel: 966-12-689-5922. E-mail: dmukauh@yahoo.com
}

Received: July 5, 2017

Accepted: August 21, $2017 \quad$ Online Published: November 29, 2017

doi:10.5430/wje.v7n6p12

URL: https://doi.org/10.5430/wje.v7n6p12

\begin{abstract}
In most countries of the world, 40 to $50 \%$ of students are women. However, there is greater sex imbalance in STEM fields. Indicators show that tertiary education in Arab region is high compared with gender balance in several countries; there is even imbalance in favor of women as in Saudi Arabia \& Gulf States.

UNESCO and World Bank statistics reveal that Arab women actively pursuing STEM fields e.g. in 2014, women comprises $59 \%$ of total students enrolled in computer Science in Saudi Arabia while UK and USA women enrolment were $16 \%$ and $14 \%$ respectively.

Graduate women attempt to pursue career or postgraduate degrees are often excluded on bases of their gender and marginalized therefore much less apt to enter and remain in the job, few achieve leadership positions.

In principle, there are equal opportunities for both genders in many Arab States, but social perception and prejudice determine which types of employment are particularly suitable for women or men. Removing the barriers would foster major social and economic benefits for every Arab State.
\end{abstract}

Keywords: Arab region; Arab women education; science technology engineering mathematics fields

\section{Introduction}

The Arab region is home to around 400 million people, and is one of the most youthful regions in the world. The median age is 22 years compared to the global average of 28 . About $60 \%$ of the Arab population is under 25 years of age. This puts great stress on educational, health and social systems throughout the region. (World Bank, 2016, Islam I, 2016)

Fertility among Arab women is high at 3.17 live births for every woman, while the world average is 2.8 . High fertility and high birth rate reduces Arab women's mobility and chances of gaining remunerative employment outside the home. However, there had been a remarkable decrease of such trend in Arab region in the 21st century. (World Bank 2016)

Most Arab nations determine the personal status of women based on Shari'a. (Islam SI 2004, Islam SI 2016, MENA, 2017)

\subsection{Arab Women and Education}

Over the last decade, most Arab nations have implemented reforms for women's rights and have shown increasing sensitivity toward gender issues. Currently, all Arab nations have ratified the Convention on the Elimination of all Forms of Discrimination against Women (CEDAW), although with some reservations. (Islam SI, 2004, Islam SI, 2016, MENA, 2017)

It is firmly believed that without liberating women from the oppression of illiteracy, no real political, social or economic development can take place. The emphasis on education helps to produce a skilled workforce, which will help Arab nations in developing internationally competitive industries. Many nations in the Arab region have shown a strong commitment to augment educational opportunities and to make them accessible to all eligible women. It is the most powerful means for improving women's status, a potent force for social change and against population 
explosion.

Several Arab Countries like Kuwait, Qatar, Yemen and U.A.E had no college/university education until 1960s. Today practically all Arab states have developed their own tertiary education system. (Islam SI, 2004) There has been a substantial increase in the allocation of funds for education in nearly all Arab countries, up to $25 \%$ of the public budget. Governments of some oil producing countries allot stipends to students in school as well as to their parents as an added incentive to pursue education. (UNDP-POGAR, 2017)

Across the region, Arab governments have made women's participation in higher education a priority. Women fill the lecture halls and universities campuses and in some cases, outnumber men (Figure 1). (US News, 2017, ArabDev, 2016)

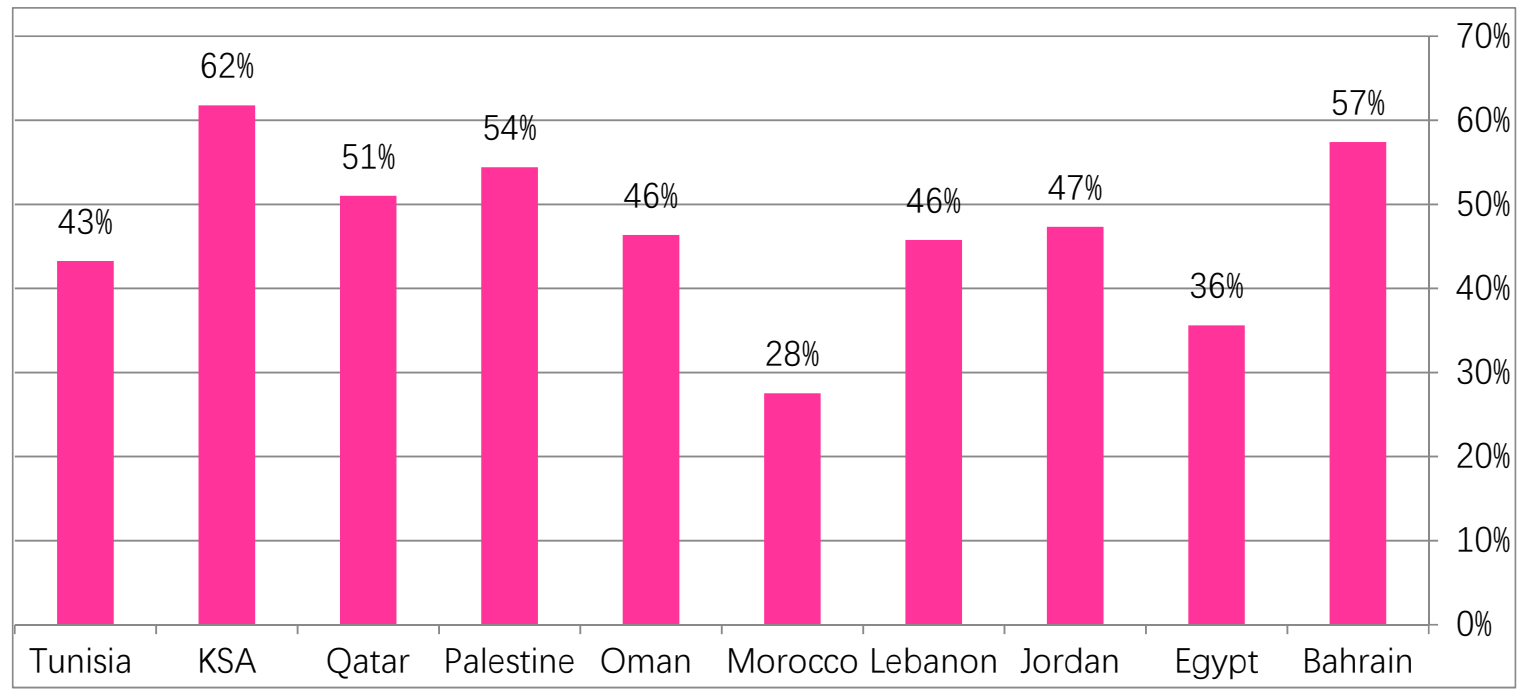

Figure 1. Women's Enrollment as a Percent of Total Student Enrolled in Some Arab Universities in 2015

In 2015 , women account for $62 \%$ of all Saudi university students, this rate is expected to increase with the opening of new colleges and universities across the Kingdom. Saudi Arabia now has 300 women's colleges, and that number is set to increase. In 2016, the Saudi government has allocated 25\% of the national budget for education. (Mohamed I., 2016, MOHE, 2015)

To improve the quality of education, the Saudi Ministry of Higher Education has launched several new initiatives, including plans to establish research excellence centers promoting creativity among faculty members, introducing research projects within the undergraduate curriculum, the translation of important textbooks, and the launch of counseling centers to support students through their years of tertiary education.

\section{Arab Woman and STEM Education}

There is a mistaken impression that Arab women do not pursue STEM fields because science and mathematics are for men only. As per UNESCO and World Bank statistics, Arab women are now actively pursuing STEM subjects offered by universities in the region. For example, in 2014 women comprised $59 \%$ of the total student enrollment in Computer Science at government universities in Saudi Arabia. In comparison to UK and USA, women enrollment in Computer Science were 16\% and 14\% respectively; those numbers include international students, some of whom came from the Arab region. (NSB 2014, Universitiesuk.ac.uk, 2015, famousefemalescientist.com, 2016)

Overall, the percentage of Arab women enrolled in and graduating with degrees in STEM fields is relatively high. In certain fields, such as Health \& Welfare, Science and Agriculture, women even outnumber men in many Arab countries (Figures 2 and 2I). (UNESCO, 2017) 


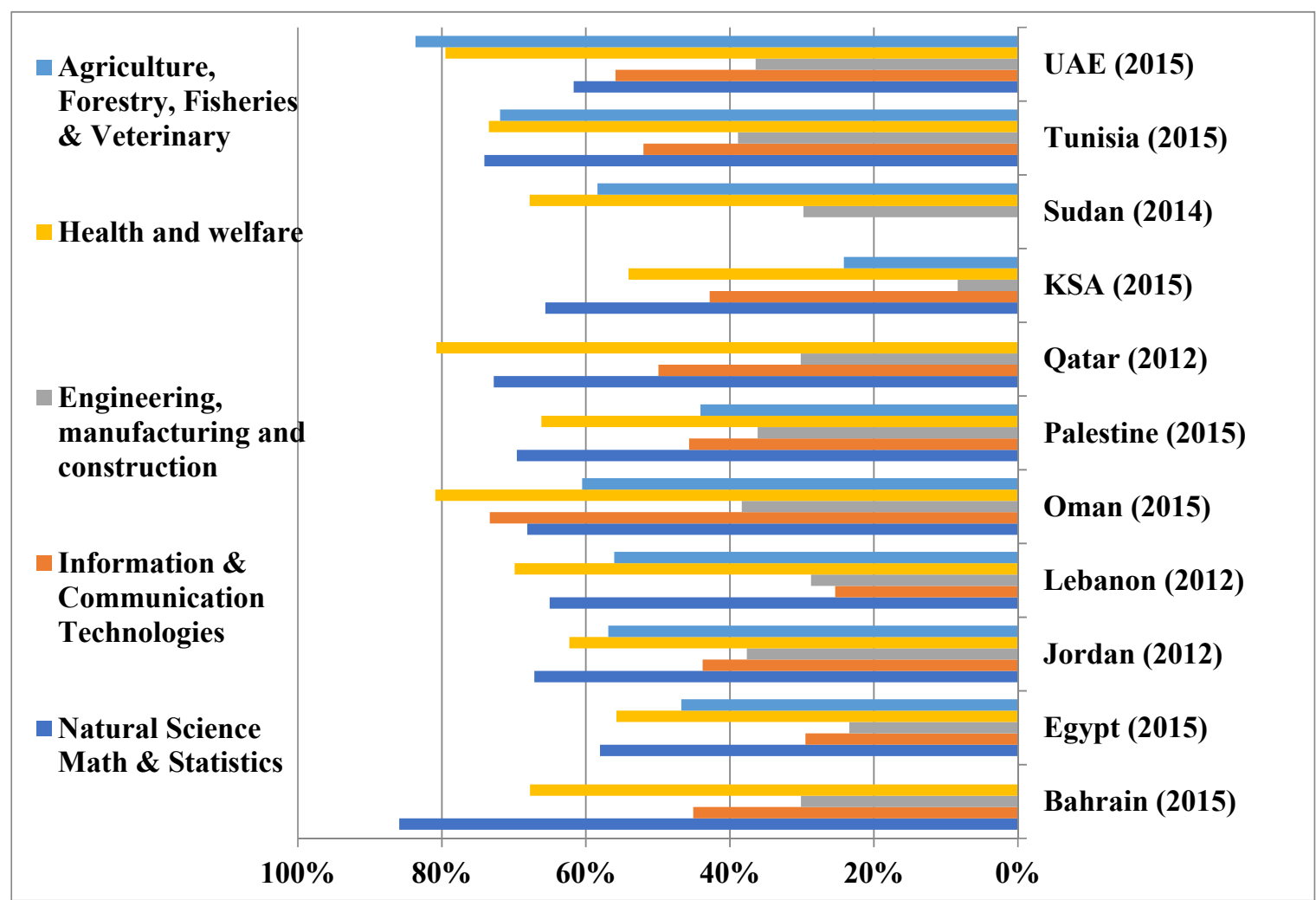

Figure 2. Women Enrolled in STEM Fields as a Percent of All Students, by Field, in some Arab Universities

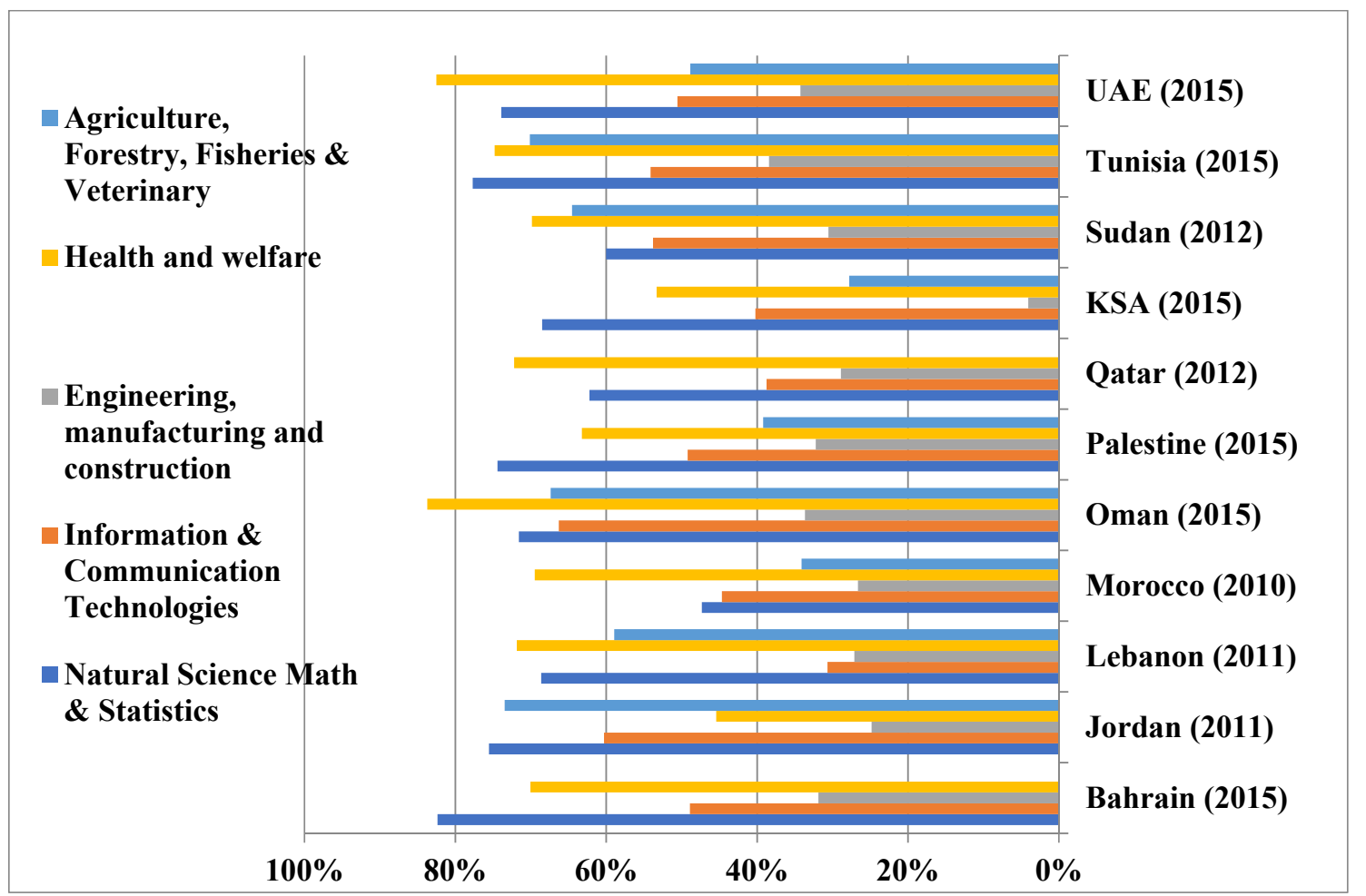

Figure 3. Women Who Have Graduated in STEM Fields as a Percent of All Students Graduated, by Field, in Some Arab Universities 
However, when these women graduate and attempt to either pursue careers in STEM fields or postgraduate degrees such as the MSc or the $\mathrm{PhD}$, they are often excluded on the basis of their gender.

\section{Careers and Employment}

It is a known fact that Arab women seek and do well in tertiary education at higher rates than men. Given this occurrence, it is empirical to note that the percentage of women teachers in the tertiary level is much less than their male counterpart (Figure 4). (UNESCO, 2017)

This results to greater workloads to women.

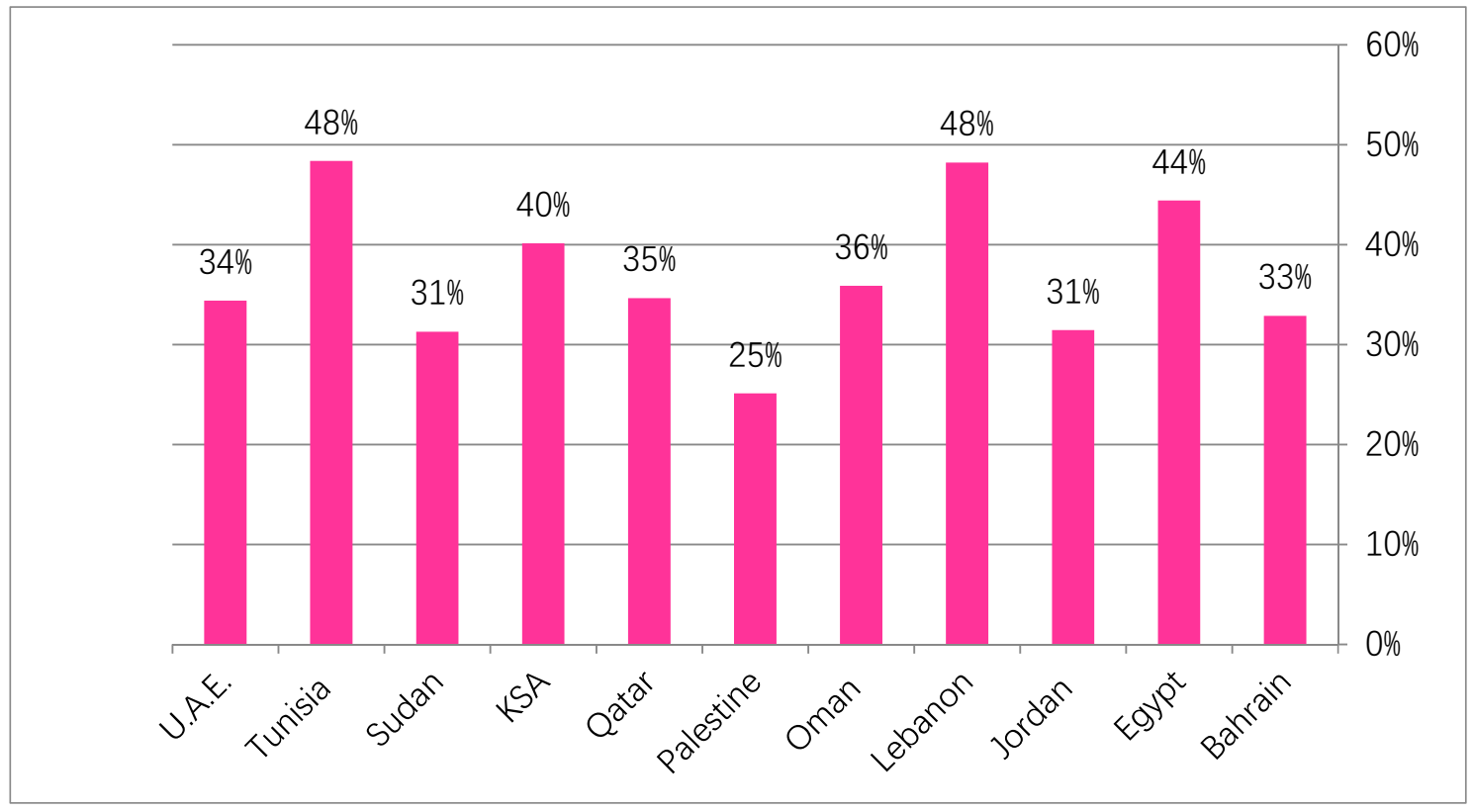

Figure 4. Percentage of Women Teachers in Universities of Some Arab Countries

Women are marginalized, and therefore much less apt to enter and remain in the job market (Table 1). (UNESCO, 2017) Removing the barriers that hinder women from working would release the enormous potential of educated Arab women, and foster major social and economic benefits for every Arab State.

Table 1. Women Percentage Share: Labor Force VS STEM Education in Some Arab Countries

\begin{tabular}{cccc}
\hline Country & $\begin{array}{c}\text { Women as Percentage of } \\
\text { total labor force (2014) }\end{array}$ & $\begin{array}{c}\text { Average percentage of women in STEM } \\
\text { fields (2015) } \\
\text { Enrolled }\end{array}$ & Graduated \\
\hline Bahrain & 19.6 & 46 & 47 \\
Egypt & 24.1 & 43 & 65 \\
Oman & 13.4 & 64 & 52 \\
Palestine & & 52 & 39 \\
KSA & 15.2 & 39 & 63 \\
Tunisia & 27.0 & 62 & 58 \\
UAE & 13.1 & 63 & \\
Arab Region & $\mathbf{2 2 . 3}$ & & \\
World & $\mathbf{3 9 . 6}$ & & \\
\hline
\end{tabular}

In Kuwait, Qatar and UAE, 70\% of university science students are women, but their numbers are much lower in work related to science and research, in which $12 \%$ were women. This phenomenon also applies in Morocco, where $70 \%$ of students enrolled in STEM fields are women, but few achieve leadership positions. (Mohamed I., 2016)

Several Arab countries assert eagerness in building knowledge-based societies but most often than not, women are not supported by strong legislation on equal opportunity for women, to assist them in successfully entering the 
workforce, to be productive and to achieve long-term economic prospects in the STEM fields.

Greater access to education without equal access to jobs represents a missed opportunity for women, their families and their nations (Table 1). Education alone does not fully protect or prepare women in the Arab region for gaining economic equality. Investment in education must be matched with national efforts to tackle all barriers to Arab women entering the job market, staying in it, and having access to positions of increasing responsibility.

\section{Results and Discussion}

In the Arab region, there is a surplus of unemployed women scientists. In Saudi Arabia for example, $57 \%$ of science graduates are women, but women's share of the total labor force is only $16 \%$ in 2015. (tradingeconomics.com 2017)

There are increasing efforts to encourage women to pursue STEM fields, from the increasing number of women's colleges to the introduction of e-learning, and tele-medicine, all of which provide more opportunities for a greater number of women to participate in STEM education.

Arab countries are making genuine efforts to become members of advanced nations. This requires bold, forward-thinking leaders who will remove the barriers and alienation of women in STEM fields. University education in most Arab countries is the product of the second half of the $20^{\text {th }}$ century. (Islam SI, 2004, Islam SI ,2016, MENA, 2017)

The acceptance of women in all academic disciplines, and their spectacular educational achievements thus far make their societies' commitment to accept and even encourage women to participate in the workforce imperative. The common attributes for success as a scientist are intelligence, creativity, hard work, and at times, a bit of luck. Women and men share those attributes. They are gender-neutral.

The paradox is that Arab women are utterly competent and absolutely sited to play a productive role in the region's labor force. Currently, female literacy rates in the Arab region are nearly equal to those of men. Considering the higher percentage of women compare to their men matching part, it can easily be concluded that women's share in the pool of talented individuals is higher than men and some Arab women outperform men even in the tough sciences. Figures show that Arab women graduates in the STEM fields are more than that of U. S. and Europe therefore Arab women have the skills in STEM fields but one big question is, why do Arab women do not have the same chance to thrive in the labor force?

Most, if not all, countries in the Arab region have accepted gender diversity in most enterprises in both the public and private sector. Successful examples are the oil producing multinational companies, Schlumberger and Saudi Aramco, which operate in the region, and have appointed women to management positions previously held by men. Schlumberger also employs women scientists and engineers in research and product centers around the world. Their commitment to gender diversity began in 1994 and their progress is noteworthy (Figure V). (Schlumberger, 2014)

\begin{tabular}{|c|c|}
\hline Females in junior management positions ( $\%$ of total junior management positions) & $19.4 \%$ \\
\hline Females in management positions ( $\%$ of total management workforce) & $17.5 \%$ \\
\hline $\begin{array}{l}\text { Females in top management positions, L.e., a maximum of two levels away } \\
\text { from CEO or comparable position ( } \% \text { of total top management positions) }\end{array}$ & $10.9 \%$ \\
\hline
\end{tabular}

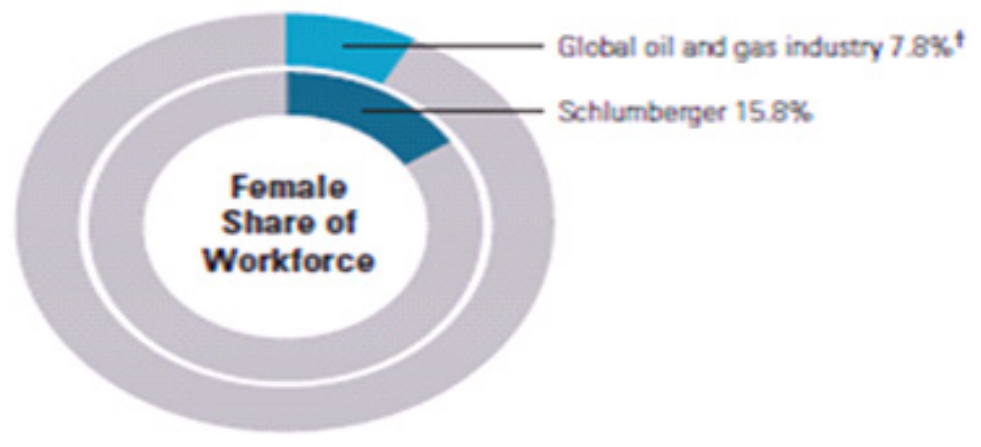

Figure V. Gender Diversity in Schlumberger in 2014 
Saudi Aramco has been a leader in hiring women for more than 50 years, beginning in 1964 when the company hired Najat Husseini and became the Saudi Aramco's first university-educated Saudi female employee. The company established the Special Clerical Training Center for Saudi women in Dhahran in 1976. In the mid-1980's, Naela Mousli became the company's first female petroleum engineer and first female department manager. Other pioneers include Samra Ibrahim Islam, the first Saudi woman who obtained a BSc. degree in Nursing and worked in Aramco's Maternal Child Care Clinic in Dahran, Thuraya Al-Arrayed, the first Saudi woman Ph.D. to live and work in the Eastern Province, and Huda Al-Ghosen, who in 2007 became a director of the company's shipping subsidiary, Vela International Marine, Ltd. All these great women worked in the STEM fields during the times when the Saudi government has no precedent and established positions for women having such degrees. (Al-Ghoson, 2015)

In 2015, Ms. Huda Al-Ghosn became Saudi Aramco's Executive Director of Employee Relations and Training, overseeing more than 65,000 employees. She is the first woman to hold this position in the company's history. In addition, 84 women are now occupying leading positions in Saudi Aramco's technical fields. In 2016, Saudi Aramco, Princess Nourah University and Wipro Arabia Limited (a leading information technology, consulting and business process services company), launched the first all-women business \& technology park in KSA. This project is expected to create around 20,000 jobs for Saudi women over a period of ten years. (Al-Ghoson, 2015)

Saudi Aramco also offers scholarships to young women to pursue STEM studies at universities around the world. (Al-Ghoson, 2015)

In support of Saudi women in STEM fields, Saudi Aramco funded the Ibn Khaldun Fellowship for Saudi women (IBK) which was launched in 2012 by Massachusetts Institute of Technology (MIT) Cambridge, USA in collaboration with other Saudi universities. The first group of Aramco sponsored fellows was admitted to the program in the fall 2013. (Malinson, 2015)

IBK was recently expanded to include 5 to 10 additional fellows to study at MIT for one year each, for the next five years.

In principle, there are equal opportunities for both genders in many Arab States. However, one of the greatest impediments that prevent women from joining the workforce is flanked by culture, religion and industry needs along with the absence of solid and practiced anti-discrimination policies. Social perception and prejudice determine which types of employment are particularly suitable for women or men. Women in universities (Figure 4), research institutes and scientific organizations (Table 2) are considerably more limited than those for men, particularly in senior positions. This prevents women from performing in their roles.

Table 2. Women Researcher (FTE) as Percentage of Total Researchers in STEM Fields in Some Arab Countries (UNESCO, 2017)

\begin{tabular}{cccc}
\hline Field & Country & Year & $\%$ \\
\hline & Bahrain & & 41.1 \\
Natural Sciences \& Engineering & Egypt & 2015 & 40.03 \\
& Iraq & & 39.03 \\
\hline & Egypt & & 31.96 \\
Agriculture, Fisheries \& Veterinary & Iraq & 2014 & 29.76 \\
\hline Health \& Medical & Bahrain & 2014 & 14.60 \\
& Egypt & 2015 & 27.96 \\
& Iraq & & 11.57 \\
& Oman & & 4.26 \\
& UAE & & 6.02 \\
\hline
\end{tabular}

To achieve balanced national development, women are needed in the various areas where their functions are most suitable. Arab women have made great strides over the decades, breaking stereotypes and emerging successful in professional careers. Many Arab women already have distinguished themselves as physicians, chemists, physicists, 
engineers, doctors, judges, lawyers, journalists, poets, novelists and even legislators. (Islam SI, 2004 \& 2016)

Arab nations have benefited from the contributions of women in those fields, but barriers to women's full participation in the workforce still exist. Bringing down those barriers would unlock Arab women's potential and yield significant social and economic benefits to every Arab state.

It is worth noting, however, that many of the challenges faced by women when it comes to career opportunities are not unique to the Arab region. For example, In Australia, 50\% of students enrolled in natural and physical sciences; $15.5 \%$ in information and engineering related technologies were women in 2015 but women accounted for less than one in eight (11.8\%) engineers in Australia's labor force. Only $27 \%$ and $13 \%$ of women graduates with a STEM degree were working in STEM-related jobs in Canada and the U.K respectively. In the U.S.A., women occupy fewer than $25 \%$ of STEM jobs, and only $11 \%$ of technology-related businesses have female founders or CEOs. (Tucker, 2014)

Gender equality entails access to top jobs, equal pay, and flexible working hours that help support women in balancing their roles as productive members of the labor force and as primary care-givers, issues that remain worldwide challenges.

\section{Inspirational Women Role Models}

History has well demonstrated that women can be on the forefront of discovery in both science and medicine. Perhaps the best-known woman scientist is Madame Marie Curie, who shared the Nobel Prize in Physics with her husband Pierre and Henri Bequerel in 1903, and in 1911 was awarded a second Nobel in Chemistry for her discovery of polonium and radium. Fifteen women have won Nobel Prizes in science since Madame Curie's successes. Such role models can encourage girls and women to pursue careers in the STEM fields and prove the common perception that "men are better suited for the job" to be wrong.

The number of women who have been successful in careers that were once the sole domain of men in the Arab region is increasing. Their life stories are an inspiration to our Arab women. Here are several examples:

- On September 27, 1933, Lotfia El Nadi became the first Egyptian woman to earn a pilot's license. She was among the youngest at the time, age 26, to achieve her lifelong dream;

- Sameera Moussa was a nuclear scientist who dedicated her life to making medical nuclear power affordable to all;

- Nadya Bakhurji, was the first Saudi woman to become a board member of the Saudi Council of Engineers and has campaigned for the recognition of Saudi female architects and engineers in the Kingdom;

- Zaha Hadid is an Iraqi born architect, considered one of the greatest living architects. She is the first woman to win the Pritzker Architecture Prize. Inspired by the fluid geometry of water in motion, Zaha Hadid's London Aquatic Centre is considered the "most majestic" Olympic spaces;

- Faiza Al Khorafi is a well-known Kuwaiti scientist who was appointed president of Kuwait University. She was the first woman to head such a large educational institution in that country;

- Mariam Mirzakhani is an Iranian-born, Harvard-educated mathematician, now a professor at Stanford University in California. She became the first woman to win the prestigious Fields Medal, also considered the "Nobel Prize for Mathematics";

- Nashwa Eassa is the 2015 winner of the Elsevier Foundation Award for Women in Science in the Developing World", and founder and president of the Sudanese Women in Science Organization.....and the list continues.

The above are Arab women, all of whom have made a difference in Arab society. They are role models in STEM fields, and their numbers are increasing in the Arab world.

\section{Awards and Recognition}

Accomplishing something in the competitive STEM fields is difficult under any circumstances. But being a woman scientist in a region wherein resources are limited, and cultural and traditional norms present barriers for women to pursue careers in STEM fields and then to succeed in them, is especially challenging. The L'Oreal-UNESCO "For Women in Science International Awards" and the Elsevier Foundation "Awards for Women in Science in the Developing World" serve as incentives for women in the developing world to pursue STEM careers. 
The L'Oreal-UNESCO "For women in Science International Awards" honor and celebrate great women scientists from the past and contemporary, to create role models and inspire the next generation of women scientists. Already 88 L'Oreal-UNESCO laureates, $11 \%$ of the total, are Arab women. (L'Oreal, 2017)

The Elsevier Foundation Awards for Women in Science in the Developing World, and Awards for Early-Career Women Scientists in the Developing World recognize the achievements of researchers who have made significant contributions to the advancement of scientific knowledge. This program is run by The Academy of Sciences for the Developing World (TWAS), the Organization for Women in Science for the Developing World (OWSD), and the Elsevier Foundation. (Schemm, 2015)

\section{Recommendations}

Family and parenthood are still vital social tenets in Arab society. Customarily, the women perform the key role in taking care of the home which undeniably deters their professional growth.

The acceptance of women in all branches of university education and their spectacular educational achievements has made the commitment of women to the work place. Multi-national companies such as Schlumberger and Saudi Aramco should establish a state of the art research centres and facilities within the region to become accessible to scientists for advance training within their countries.

Different Arab countries may adapt different approaches to remuneration based upon support for R\&D and policy objectives on establishing medical technology research in the region whereby women scientist would gain access and carry on effective innovation and knowledge production system in their countries.

Giant multinational drug companies will be forced to establish their research centres in the region in order to avoid the high royalties forced upon them if the governments of Arab States make advantage of the flexibilities provided by the TRIPS Agreement.

Cooperative scientific projects with female science/medical and IT graduates could have several mutually beneficial outcomes including: (1) Help raise the profile of Arab women as productive scientists, (2) Allows women "well settled" within their own society, (3) Facilitate the transfer of technology, (4) Be an example of positive exchange between the Arab world and the west, (5) Provide scientists from outside the region access to an under researched region.

Bill Gates once said "If you're not fully utilizing half the talent in your country, you're not going to get too close to the top". Since women comprises half of the Arab world's population therefore Arab countries need to embrace women's political, social and economic potential, for prospective growth and diversification of their respective economy.

\section{References}

Al-Ghoson H. (2015). Women leaders in the Gulf: The view from Saudi Aramco. Retrieved from www.saudiaramco.com

Best Arab Region $\quad$ Universities Rankings Retrieved from http://www.usnews.com/education/arab-region-universities/rankings

Education in Arab countries. $\quad$ Retrieved from http://www.arabdevelopmentportal.com/datahighlighted/education-attainment-arab-countries

Education Observatory (2015) Education in Saudi Arabia local Indicators and International Comparisons. Retrieved from http://mohe.gov.sa/Lists/OHEReports/Attachments/14/Report.pdf

Famous Female Scientists - Greatest Women Scientists Ever. Retrieved from www.famousfemalescientists.com

Islam SI (2004). Role of Women in the Modern Arab Science, (Contribution to) AAAS Annual Meeting, Washington D.C., U.S.A.

Islam SI, (2016). Arab Women and STEM fields (contribution to) Fourth Arab Forum on Scientific Research and Sustainable Development, Cairo Egypt

Labor force - female (\% of total labor force) in Saudi Arabia Retrieved from http://www.tradingeconomics.com/saudi-arabia/labor-force-female-percent-of-total-labor-force

Malinson A. (2014). Supporting Saudi Arabian female scientists and engineers. MIT News on campus and around 
the world. Retrieved from http://news.mit.edu/2014/ibn-khaldun-postdoctoral-fellowships

Middle East and North Africa: Youth Facts |Youthpolicy.org Retrieved from www.youthpolicy.org/mappings/regionalyouthscenes/mena/facts retrieved April 6, 2017

Mohamad I. 2016. Kingdom tops world in education spending. Arab news. Retrieved from http://www.arabnews.com/saudi-arabia/kingdom-tops-world-education-spending

National Science Board (2014). Science and Engineering Indicators 2014. Arlington VA: National Science Foundation (NSB 14-01) Retrieved from http://www.nsf.gov/statistics/seind14/content/etc/nsb1401.pdf

Patterns and trends in UK higher education, 2015. Retrieved from http://www.universitiesuk.ac.uk/highereducation/Documents/2015/PatternsAndTrends

Schemm Y. (2015). Here are the winners of the Women in Science Elsevier Foundation Awards - meet them. Retrieved from https://www.elsevier.com/connect/women-in-physics-and-math-to-receive-elsevier-foundation-awards-at-aaasmeeting

Schlumber Global Sterwart Repost 2014 Retrieved from http://www.slb.com

The L'Oréal-UNESCO For Women in Science Programme. Retrieved from https://www.womeninscience.com

Tucker L. (2014). Scholarship for women in a male dominated industries. Retrieved from http://www.topuniversities.com/student-info/scholarship-advice/scholarships-women-male-dominated-industrie $\mathrm{s}$

UNDP-POGAR: Programme on Governance in the Arab Region: Gender Retrieved from http://www.pogar.org/themes/gender

UNESCO institute of statistics. Retrieved April 6, 2017 from http://data.uis.unesco.org retrieved

World Bank (2016). The Arab World. Retrieved from http://data.worldbank.org/region/arab-world retrieved April 6, 2017 